\title{
Ulusal Eğitim Meselesine Sinemanın Gözünden Bakmak: Entre Les Murs (Fransa) ve İki Dil Bir Bavul (Türkiye) Filmleri Üzerine Bir Karşılaştırma
}

\author{
DOI: 10.26466/opus.591147
}

\author{
* \\ Serhat Yetimova* \\ * Dr. Öğretim Üyesi, Aydın Adnan Menderes Üniversitesi \\ E-Posta: serhat.yetimova@adu.edu.tr \\ ORCID: 0000-0001-5674-0284
}

Öz

Küreselleşme sürecinde ulusun inşa ettiği tüm değerler birer tartışma konusudur. Ulusal eğitim de bu tartışmanın bir boyutunu oluşturmaktadır. Çok kültürlülük/kültürcülük, çok kimliklilik gibi alt başlıklarla sahip bir kavram olarak küreselleşme milli eğitim anlayışının değişmesinde oldukça önemli bir etkiye sahiptir. Bu gelişmeler katı etnik-ulusalcı yaklaşımlar sergileyen kimi ülkelerde önemli çatışmaların da konusunu oluşturmaktadır. Özellikle 2005 Paris İsyanlarında Fransa'nın içine girdiği ulusal eğitim tartışması günümüzde de geçerliğini tüm canlılığıyla korumaktadır. Türkiye de hakeza Kürt toplumu ve son zamanlardaki Suriyeli göçmenlerle benzer bir tartışmanın öznesi konumundadır. Bu makale sinemanın aracılı̆̆ında küreselleşme sürecindeki ulusal eğitim olgusuna yönelik nasıl bir söylem geliştirildiğine Türk ve Fransız yönetmenlerin gözünden bakmaktadır. Karşılaştırmalı söylem analizi yöntemini kullanan bu makale, örneklem olarak Fransa'dan Entre Les Murs (Duvarlar Arasinda, 2008, Laurent Cantet) ile Türkiye'den İki Dil Bir Bavul (2008, On the Way to School, Özgür Dogan, Orhan Eskiköy) filmlerini konu ve senaryo bakımından ulus söyleminin tarihsel gelişimini dikkate alarak karşılaştırmal olarak incelemiştir. Her iki filmin ideolojik bir tutum sergilemek yerine sürece insani ve kültürel olarak yaklaştı̆̆g tespit edilmiştir. Her iki filmde de ulus kavramının türevleri olarak ulusal kimlik ve ulusal eğitim, modernleşme sürecinin bir parçası olarak tanımlanmış; Fransız ve Türk eğitim sisteminin kültürel türdeşlik ve medenileşme sağlamadan ve teknik altyapı zeminini oluşturmadan popülist politik yaklaşımlar sergileyerek ötekileri uluslaştırmanın bir parçası yapmaya çalıştı̆̆l değerlendirmesinde bulunulmuştur. Her iki filmde de birer idealist öğretmen öne çıkarılmış ötekileştirmeden bağımsız milli olarak değil insan olarak hareket eden varliklar olarak resmedilse de büyük resmin içinde görünür olamadıkları yönünde değerlendirmede bulunulmuştur.

Anahtar Kelimeler: Fransa, Fransız Eğitim Sistemi, Türk Ĕ̆itim Sistemi, Sinema, Fransız Sineması, Milli Ĕgitim 


\title{
Looking at National Education from the Viewpoint of Cinema: A Comparison of Entre Les Murs (France) and On The Way To School (Turkey)
}

\begin{abstract}
Globalization transforms everything within notional values and national education as well. Multiculturalist or multicultural and multi-ethnicity approaches also give effects on national education and politics in the context of globalization. This flow like as ethnic-based national politics brings to light of social conflict among national society and the others. Especially 2005 riots of France and long lasting Kurdish society and recent Syrian migration of Turkey force them to be subject of the problem that has strong arguments on national systems within identity and integration through education. This article tries to determine etymological changes of nationalism and its effect on national education debate through the eyes of Entre Les Murs (2008) and On the Way to School (2008) and its national directors. Both of films have non-ideological perspective and search for humanitarian values of nationalists and the others. Both of films criticize the nationalism as a sub-term of modernism instead of feudalism. Lack of cultural equality and civilisation and technical infrastructure of education system in France and Turkey cannot transform the whole society to be gathered under the co-nationalism umbrella. It causes greying of personal, humanitarian effects of two idealist and hero teachers on their student in the films. All this kind of mis-opportunities of French and Turkish modernisation for their whole society means populist politics continue to shape the education but partially.
\end{abstract}

Keywords: France, French Education System, Turkish Education System, Cinema, French Cinema, National Education 


\section{Giriş}

1789 Fransız ihtilalinin dünyaya armağanı olan ulus ${ }^{1}$ fikrinin temelinde halk düşüncesi yatsa da tarihsel çıkış noktasına bakıldığında feodal düzenin merkezindeki krallık rejimine karşı olan halk hareketi anlaşılmaktadır. Fakat ulus kavramı tarihsel süreç içinde dönemsel olarak cumhuriyet anlayışının değişimine paralel olarak etimolojik bir değişiklik geçirmiş her dönem çok farklı şekillerde anlaşılmıştır. Fransız siyasetçi Danton'un yaşadığ 1 dönemdeki ulus fikri ile İmparator Napolyon dönemi nasıl farklı ise benzer şekilde Sarkozy döneminin ulusçuluk anlayışı ile Mitterrand dönemi Fransız ulusçuluğunun benzeşmemesi ulus fikrinin birbirinden apayrı bir tarihsel iz düşüme sahip olduğunu göstermektedir².

Türkiye'deki sürece bakıldığında da benzer şekilde Tanzimat dönemi ile başlayan Osmanlılardaki ulus düşüncesinin İslamcılık, Türkçülük ve Osmanlıcılık gibi farklı tezahürler yaptığı görülürken erken cumhuriyet (Atatürk dönemi) dönemindeki ulus anlayışı ile yakın dönemdeki (özellikle Özal dönemi) ulus söylemi de birbirinden tamamen farklı özellikler göstermiştir. Bu dönemsel yorumların ardında Batı merkezli siyasal (modern) ve ekonomik (kapitalist) dünya görüşünün çok temel bir yapısal etkisi bulunmaktadır. Günümüzde küreselleşme sürecine bağlı olarak ulus düşüncesinin daha çok neo-liberal ekonomi düzenin kavram kiti olarak

\footnotetext{
1 Ulusçuluk (Fr. Nationalisme) fikrinin ortaya çıkışının arka planında kültürel ve dilsel özdeşliği bulunan bir topluluğun bağımsız bir politik yapı olarak örgütlenmesi ve egemenliğini örgütleşerek kurması; yani devlet olması yer almaktadır. Kavramın özellikle Batı Avrupa toplumları için içerdiği temel sosyolojik anlam feodalizm rejimine ait yönetim biçimleri içinde yer alan krallık ve senyörlük gibi yönetsel erkler karşısında çoğunluk olan bir halkın, ortak bir dil, din, kültür, toprak ve ekonomi merkezinde bir bütün olarak hareket etmesi ve bu birliği ortadan kaladırmaya dönük her türlü yabancı müdahaleyi reddetmesi yönünde karşılık bulmaktadır (Larousse, 2016).

2 Çok kültürlülük tartışmasına farklı bir pencereden bakan Delannoi (1998, s.35-36) her kavramın olduğu gibi milliyetçiliklerin de sürekli bir değişim içinde olduğunun altını çizmektedir. Birinci Dünya Savaşı, milliyetçilik ve sömürgeciliğin egemenlik yarışına sahne olmuşken ikinci Dünya Savaşı'nın ise daha çok liberaldemokratik değerler ile komünist ve ırkçı ideolojilerin hâkimiyet mücadelesine sahne olduğu görülmüştür. Bu bağlamda Alman milliyetçiliğinin felsefi, tarihselci ve romantik karakteri ikinci Dünya Savaşı yıllarında nasyonal sosyalizme evirilmesi milliyetçilikte yaşanan tarihsel-zamansal değişime işaret etmektedir. Bu sebeple Delannoi (1998) milliyetçiliklerin yerelliklerin taşıyıcısı olabileceği gibi evrenselliklerin de taşıyıcısı olabileceğini savunmaktadır. Wenden (1998, s.40) 1871 Paris Komününde Jules Michelet tarafından tanımlanan milliyetçiliğin halkçı karakter, Maurice Barrés ve Charles Maurras'ın milliyetçiliğinin ise bölgesel, seçkinci, muhafazakâr, korumacı, yabancı düşmanı ve anti parlamenter değerler taşımasını bu zamansal değişime örnek olarak göstermektedir.
} 
göç, terör, sığınma, faydacılık (pragmatizm) ve güvenlik gibi bir kavram ilişkili olarak yorumlandığına tanık olunmaktadır.

2005' te Fransa'nın banliyölerinde yaşanan göçmen isyanları Fransa'nın milliyetçi söylemleriyle dünya gündeminde manşet olduğu bir dönemdi. (Cnnturk, 2005; Euronews, 2015) Banliyö isyanları ile birlikte ulusalcı politika tartışmalarının hararetli şekilde yaşandığı bir dönemde Duvarların Arasında (Entres Les Murs, 2008) filmi ile Fransız yönetmen Laurent Cantet, Fransa'nın küreselleşme bağlamındaki ulusal kimlik ve kültürel entegrasyon sorunlarına eğitim sistemi üzerinden bakmaya çalışmış; göçmen ve Fransız toplumu arasındaki etkileşimi görünür kılmıştır. Cantet, filmde hem ulusalcı söyleme hem de göçmenlerin düşünce dünyalarına empatik bir yaklaşımla eğilmiş, güncel politika yerine kültürlenme sürecine odaklanmıştır.

Türkiye' de ise özellikle 2000'lerle birlikte siyasette sivilleşme hamleleri ile başlayıp sonrasında "çözüm süreci" ile devam eden süreçte Kürtlerin hem kültürel hem de siyasi olarak daha aktif şekilde temsil edilmesini sağlamaya yönelik bir dizi gelişme yaşanmıştı. Böyle bir süreç içinde İki Dil Bir Bavul (Eskiköy ve Doğan, 2008) filmi de Kürt kökenli vatandaşların çoğunlukta olduğu ve politik bakımdan sorunlu bir bölgedeki eğitim uygulamalarını tartışmaya açmıştır. Filmi ilgi çekici kılan nokta konuya siyasal ve ideolojik bir pencereden bakmak yerine eğitim ve iletişim kültürü üzerinde eğilmeye çalışmasıdır.

Göçmenlik ve daha geniş anlamda öteki konusu sadece göçmenler tarafından ele alınmış bir konu değildir. Fransız yönetmenlerin göçmenliği ele aldığı yakın dönemdeki çalışmalar da bir hayli fazladır. ${ }^{3}$ Bunlar arasında Philipe Loiret'in Welcome'ı (Hoşgeldiniz, 2009), François Dupeyron'un Monsiuer Ibrahim et Les Fleurs du Coran'1 (İbrahim Bey ve Kur'anın Çiçekleri, 2002), Jean Jacques Annaud'un L'Amant'1 (Sevgili, 1991), Mathieu Kassovitz'in La Haine (Nefret, 1995) ve Metisse (1993)'i, Regis Warnier'in Est-Ouest (Doğu-Bat1, 1999)'i, Cedric Claphisch'in L'Auberge Espagnole (İspanyol Pansiyonu, 2002) ve Les Poupées Rousse (Rus Bebekler, 2004) adlı filmleri Fransızların göçmen topluma ve ötekilere bakışını gösterir filmlere ilk bakışta örnek olarak verilebilir. 
Fransız yönetmenlerin gözünde göçmenler ve ötekilik meselesi daha çok kültürel farklılık, yolculuk, ötekinin keşfi, yeni değerlerle buluşma, entegrasyon sorunları ve kimi zaman da Fransız toplumunun eleştirisini içermektedir.

Fransa' daki göçmenlerin yakın tarihinin Milli Futbol Takımı üzerinden incelendiği Les Bleus Une Autre Histoire De France (Maviler, Fransa'nın Alternatif Tarihi, 2016, David Dietz, Sonia Dauger, Pascal Blanchard) adlı belgesel göçmen futbolcuların ne kadar başarılı olsalar da katı milliyetçi bir tutum sergileyen Fransiz toplumuna ve onun ulusalcı kurumlarına kendilerini kabul ettirme noktasında ne kadar başarısız olduklarını göstermekte; bu yönüyle Fransız toplumunu eleştirmektedir.

Türkiye'de ise Türk yönetmenlerce Kürtlerin konu edildiği filmler de hatırı sayılır bir yoğunluktadır. Bunlar arasında Hakkâri'de Bir Mevsim (K1ral, 1983) Kürtlerin yaşam koşullarını eğitim üzerinde ele alırken Press (Basın, Sedat Yılmaz, 2010)'in basın ve ifade özgürlüğü konularına değindiği görülmektedir. Özgür Gündem gazetesinin Diyarbakır şubesindeki gelişmeleri anlatan Press filmi dönemin militarist siyasetinin eleştirisini bölgedeki gazetecilik faaliyetleri üzerinden yapmaktadır. Benzer şekilde $B \ddot{u}$ yük Adam Küçük Aşk (İpekçi, 2001), Nefes (Semerci, 2009) gibi filmler de son dönemde Kürt konusuna "sosyolojik" ve "kültürel" açıdan yer veren diğer önemli çalışmalar arasında değerlendirilmektedir. Günümüzde ise daha çok popüler televizyon dizi ve filmleri ile konunun savaş ve aksiyon yönleri ön plana çıarılmaktadır. Türkiye' de de Kürt toplumuna son dönemde kentlilik, sanat, toplumsal cinsiyet, ekonomi ve eğitim gibi modernizmle ilişkili konular üzerinden bakan yönetmenler ve filmler görülmektedir. Seren Yüce'nin Çoğunluk, (2010) ve Emin Alper'in Tepenin Ardl (2012), Murat Saraçoğlu ve Mehmet Gezen'in Yangın Var (2011) Özcan Alper'in Gelecek Uzun Sürer (2011) ile Ahu Öztürk'ün Toz Bezi (2015) bunlara örnek olarak verilebilir (Çiftçi, 2012).

\section{Yöntem}

Bu makale, milli eğitim olgusunu gündemlerine almalarından ötürü Entre Les Murs ile İki Dil Bir Bavul adlı filmlerin ulusa ve ulusal eğitim düşüncesine nasıl yaklaştıklarını karşılaştırmalı söylem analizi yöntemini kullanarak çözümlemeye çalışmaktadır. Her iki filmin bir diğer ortak özelliği ise 
yönetmenlerinin Fransız ve Türk oluşu olup içinde yaşadıkları toplumun ötekisi olan göçmen ya da azınlıklara bakışını içermesidir.

Söylem analizi bağlamında incelenen bu filmlerin senaryo içerikleri karşılaştırmalı olarak incelenmekte olup diyaloglarda öne çıkan düşünce, konu, kişi, eser ve sembollerin vücut verdiği "ulus" ve "öteki" söylemleri anlaşılmaya çalışılmaktadır.

Ulus kavramının günümüzde nasıl bir anlama ulaştığı tarihsel veriler ışığında ayrıca değerlendirilmektedir. Bu değerlendirme neticesinde bugün için ulus kavramının literatürde nasıl bir anlama kavuştuğu belirlendikten sonra belirlenen filmlerdeki ulus tartışması ile uyumuna ve "öteki" ile kurduğu ilişkiye bakılmaktadır.

\section{Milliyetçilik ve Ulus Söyleminin Tarihsel Gelişimi Bağlamında Fransa ve Türkiye}

Başlangıçta aristokrasi ayrıcalığının son bulması ve sembolik eşitlik gibi değerlerle Fransız devriminin birer meyvesi olarak ortaya çıkan ulus ve yurttaşlık kavramı, 1800'lü yıllarda endüstri devrimleri, 1950'li yıllarda da artan küreselleştirici koşulların etkisiyle başlangıcından çok farklı anlamlara sahip olmaya başlamıştır. ${ }^{4}$ Kaya (2003), modern yurttaşlık kavramının temel çıkış noktasını bireyin devlet ile olan ilişkisinde hak ve yükümlülüklerin anayasal bir sözleşme ile teminat altına alındığı bir modelde bulmaktadır. Bu bakımdan modern yurttaş bir takım medeni, toplumsal, kültürel ve ekonomik haklardan yararlanmak için oy kullanarak siyasal karar alma süreçlerine katılan kişi olarak görülmektedir. (Kaya, 2006, s.3738).

Fransız ulusçuluğu konusunda öne çıan düşünürlerden Renan'a göre ulusun temelinde tarihsel köklerden gelen dil, dayanışma, ahlaki bilinç, ortak kültür ve birlikte yaşama arzusu (désir de vivre ensemble) içinde olmak yer almaktadır. Renan, grup dayanışması ve bağlılık için bu arzunun gerekliliğine dikkat çekerken ortaya koyduğu yaklaşım bu anlamda dayatmacılıktan uzak demokratik bir karakter de taşımaktadır. Renan'nın

\footnotetext{
4 Bunlar arasında çoğul yurttaşlık (kozmopolitan yurttaşlık/multiple citizenship), çok kültürlü yurttaşlık (multicultural citizenship), ulusötesi (post-national), diasporik (diasporic), ulusaşırı (transnational), esnek (flexible) gibi yurttaşlık en sık karşılaşılanlar arasındadır (Kaya, 2006, s.37-38).
} 
düşüncesindeki ortak yaşama isteği insani bir güdüden çok "tarihsel kodlarla örülmüş bir gelenekten" beslenerek "ortak bir yaşam kültürünün" ortaya çıkardığı bir "tarihsel dürtü" olarak öne çıkmaktadır. Renan'ın ulusu rrka ve renge bakılmaksızın toplumun dilini ve tarihini öğrenmeye istekli "herkese" açıtır (Akkaya, 2004, s.71-73). Bu yaklaşım günümüzde dünya toplumlarını; ülkeleri ve bu arada Türkiye' yi de oldukça etkilemiş bir yaklaşımdır.

Schnappe (1991) ve Gellner (1983) gibi düşünürler ise bir ulusu inşa etmek için egemenlerin dil, eğitim, okul ve ordu gibi birçok kurumun varlığına ihtiyaç duyduğunu belirtmektedir. Bireyi kişiselliğinden ve yerelliğinden (soy, klan, aile, mezhep) kurtarıp onu ulusun hem düşünsel hem de kamusal varlığının etkin bir parçasına dönüştüren; onu toplumun ekonomik ve sosyal hayatına hazırlayan sistemin eğitim olduğu düşünülmektedir. Gellner (1983) bu bakımdan kültürel türdeşliğin oluşması adına ortak bir tarih ve toplumsal bilincin kazanılmasında eğitim ve okul sistemini temel birer yapıtaşı olarak görmektedir. Ulusu var eden kurumlardan biri olarak görülen dil ise bir ulusun kimliğinin ayırt edici özelliği ve toprak birliğinin bir garantisi olarak kabul edilmektedir ${ }^{5}$ (Akkaya, 2004, s.74).

Wenden (1998, s.39-42) göç, bölgeselleşme ya da küreselleşme gibi ulus aşırı etkilerle toprak ya da kana bağlı ulusal yurttaşlıkların yerini daha "dar yurttaşlıkların" aldığını, demografik ihtiyaç, hakların karşılıklı oluşu gibi nedenlerle günümüzde daha çok Avrupa Birliği gibi üst yurttaşlık biçimlerinin görülmeye başladığını belirtmektedir. Uyruk olmadan da yurttaş olabilmek, tarihsel-yerel şartlara bağımlı olmadan bir ulusun hukuken parçası konumuna gelmek türünden günümüze özgü durumlar vatan,

\footnotetext{
5 "Fransa örneğinde dilde birlik 1789 Bildirisi'nde kullanılan dilin, ulusal bir dil olarak bütün Fransızlar için geçerli kılınması amacıyla ve merkezi eğitimin yaygınlaşmasıyla sağlanmıştır. Bölgesel diller olarak nitelendirilen Baskça, Almanca, Korsika'da konuşulan italyanca, Brötonca ve otuza yakın taşra ağzı, ulusal birliğin önünde bir engel olarak görüldügünden 1794'den sonra yerel dillerin ve lehçelerin kamusal işlerde ve özel alanda kullanımı yasaklanmıştır" (Nalbant, 1997, s.69-70'den Akt. Akkaya, 2004, s.75) "ikinci dünya savaşından sonra 19 Aralık 1952 tarihli Deixonne yasası ile Fransa'da beş bölgesel dilin varlığı hukuken kabul edilmiştir. Bunlar Baskça, Brötonca, Korsika dili ve Katalancadır. Devletin resmi dili Fransızca olarak korunmakla birlikte, 1982 tarihinde yapılan düzenlemelerle daha önce tanınan bu dillerde ihtiyari ve sınırlı olmak şartıyla öğretim olanağı açılmıştır. Alsace ve Lorraine bölgesinde 1991'den itibaren Almanca öğretim (Almancanın bir ağzı olan Hochdeutsch) de kabul edilmiştir. Ancak, okullarda ders dışında bu dilleri ve lehçeleri konuşmak yasaktır. Benzer şekilde anaokulu sınıflarında iki dille eğitim talebi reddedilmiştir. Yine bu girişimler resmi dilden bir taviz anlamına gelmeyip, bölge dillerinin ve kültürlerinin korunması şeklinde yorumlanmaktadır. Çünkü söz konusu bu diller, ulusal azınlık dili olarak değil; bölgesel yerel dil olarak kabul görmektedirler" (Huy Heraud, 1993, s.102vd.'dan akt. Akkaya, 2004, s.76)
} 
yurttaşlık ve ulus kavramlarını da topyekûn bir değişime zorlamaktadır. Bu bağlamda Maastricht (1992) anlaşmasının ortaya koymaya çalıştığı uyruk olmadan da yurttaş olabilmek ve egemenliğin tayininde söz sahibi olmak anlayışı çok kültürlülük ve hakların karşılıklılığı gibi esaslara vurgu yapmaktadır.

Günümüzde "ulus-devletlerin, en azından kurucu temsilleri bağlamında, ulusal modeller formüle edilmesine yol açarak tarihlerini oluşturan cumhuriyet, birlik, eşitlik" gibi fikirsel eğilimlerin aksine, bugünkü genel eğilimin "kimlik pazarlıkları" yönünde olduğu kabul edilmektedir. Pazarlık konusu yapılan kimlikler ekonomik ve siyasal çıkarlar noktasında gerek iç ve gerekse de dış politikada malzeme olabilmektedir (Kastoryano, 2000, s.21).

Ulusal kimlik tartışmalarının günümüzde çeşitlendiği görülmektedir. Fransa, "çeşitlilik-üstü-bütünlüğe" vurgu yapan ülkeler arasında görülürken asimilasyon, kültürel, dinsel ve etnik farklılıklara kapalı, laik, modern, Batı-merkezci evrensel değerleri yüceltir bulunmaktadır. Çok-kültürcü yaklaşımın baskın olduğu ülkelerde ise "çeşitlilik-içinde-bütünlük" (unity-in-diversity) yaklaşımının benimsendiği görülmektedir. Çok-kültürcülük modelini ele alan Kymlicka, bu kavramın kolektif hakları ve azınlıkların bireysel özgürlüklerini ön plana çıkardığını savunmaktadır. "Çok-kültürcülüğün" "çok-kültürlülük" ile karıştırılmaması gerektiğinin altının çizildiği bu tartışmada kavramların ilki siyasal bir ideoloji olarak azınlık kültürlerini "sindirmeye" yönelik bir amaca hizmet eder bulunurken diğeri antroploljik/sosyolojik bir "vaka"ya işaret ettiği düşünülmektedir. "Çok-kültürcülük" konusundaki çalışmalarıyla tanınan Heitmeyer (et al. 1997), Alund $(1992,1993)$ ve Schierup (1991) bu modelde etnik azınlıkların varlıklarının sadece kültürel anlamda tanındığını, milli sermayenin paylaşım ve yönetimi konusunda eşitsizliklerin olduğunu eleştirilerinde bulunulmaktadır (Kaya, 2006, s.47-54).

$\mathrm{Bu}$ çatışmanın önüne geçmek içinse liberal ekonomik düzenin parçası olarak "kültürlerarasılık" olgusunun ön plana çıkarıldığı görülmektedir. $\mathrm{Bu}$ yaklaşımda farklılıklar yerine benzerlikler, etkileşim, alı̧̧-veriş ve sinerji bulunmaktadır. Will Kymlicka ve M. Opalski'ye göre kültürlerarasllı̆̆1 doğuran neden doğu toplumlarına özgü "ulusal güvenliği tehdit etme" anlayışı yerine batılı toplumlara özgü "adalet ve eşitlik" arayışıdır. 
Kymlica'nın savunduğu Batılı modelin dünyanın birçok yerinde uygulandığı görülmektedir (Kaya, 2006, s.47-54).

Türkiye'deki tarihsel gelişime bakıldığında ise Batılı model çerçevesinde Fransız ulusçuluğunun model olarak benimsendiği görülmektedir. Osmanlı Kozmopolitizmi'nden Avrupa Kozmopolitizmi'ne Giden Yolda Ulus Parantezi adlı makalesinde Türk Milliyetçiliğinin ilk dönem reflekslerini değerlendiren Aktar (2003, s.78), onlarca farklı ulusu barındıran Osmanlı'nın içinden Türk ulusunu canlandırmaya çalışan aydınların, yüzyıllardır süregelen İmparatorluk geleneği ile İslam'ın evrensel ilkeleri arasında sıkışıp kaldıklarını; aydınların önünde hukuksal ve evrenselci Fransız modeliyle katılımcı, tarihsel ve kültüralist Alman modeli olduğunu söyler. Aktar (2003, s.78-79)'a göre Cumhuriyetçi aydınlar, Türkçülük siyasetinin ilk yıllarında sırtlarında bulunan Osmanlılık ve İslamlık yüklerinden kurtulmak için katı Alman modelini uygulamışlar, daha sonra "kendine Türk diyen herkes Türk'tür" diyerek, evrensel ve vatandaşlığa dayalı Fransız modeline geçiş yapmışlardır.

1960'lardan günümüze gelen siyasal gelişmeleri değerlendiren Yayman (20116) özellikle 1960 darbesi ile Türk milliyetçiliğinin "Türkçe Konuş" ve "Herkes Türk'tür" söylemleriyle artışa geçtiğini, 1978-1987 ve 1987-2002 yılları arasındaki sıkıönetim ve OHAL uygulamalarının konuyu asker ve polisin güvenlik meselesine dönüştürdüğünü ve böylelikle Türk-Kürt ilişkilerinin içinde çıkılamaz bir hal aldığını belirtmektedir ${ }^{7}$. 2002' de Ak Parti ile başlayan sivilleşme sürecinde ise "Kürt Sorunu", "Çözüm Süreci"8 gibi tanımlamalarla sürecin çok daha radikal bir yapıda gelişme kaydettiği; Kürtlerin siyaset yapma kanallarında tarihte örneği görülmemiş bir gelişmenin kaydedildiği belirtilmektedir (Setav, 2011).

6 Hüseyin Yayman'nın Seta Akademi tarafından 2011 yılında yayınlanan Türkiye'nin Kürt Sorunu Hafızası adlı çalışmanda Türk-Kürt ilişkilerinin kronolojik bir bakış ve dönemsel farklılıklarla ele alındığı görülmektedir. Kürt toplumu üzerine şimdiye dek 70 raporun hazırlandığını belirten Yayman (2011) bu raporları 1990 öncesi ve 1990 sonrası diye ikiye ayırmaktadır. 1990 öncesi hazırlanan raporların devlet güdümünde güvenlik tedbirli yaklaşımlar şeklinde yazıldığı belirtilirken 1990 sonrasında daha çok sivil toplumun güdümünde bir takım raporların yazıldığı vurgulanmaktadır. 1990 sonrası raporlarda Kürt konusu artık Şark meselesi, doğu meselesi, güneydoğu meselesi, feodalite gibi daha farklı başlıklarda ele alınmaya başlanmış terör ve kimlik ile birlikte sosyo-ekonomik şartlar bağlamındaki veriler de dikkate alınmaya başlanmıştır.

7 Ayrıca Aljazeera (2013); Aljazeera (2015); Cnnturk (2014) ve Sabah (2016)’ın dönemin gelişimlerine ilişkin hazırladığı haber dosyaları incelenebilir.

8 CNN Türk'ün çözüm sürecine ilişkin hazırladığı haber dosyası incelenebilir:

https://www.cnnturk.com/fotogaleri/turkiye/baslangictan-buqune-qun-qun-cozum-sureci?page=21 
1980'ler neo-liberal anlayışta sanayi yatırımlarının ülkeler arası bir dolaşıma tabi olduğu yıllar olmuştur. Bu süreç Fransa içinde bir takım problemleri de beraberinde getirmiştir. Sanayi ve istihdam olanaklarının ucuz işçilik bakımından daha elverişli ülkelere kayması Batı Avrupa'da istihdama bağlı ekonomik sıkıntıları da beraberinde getirmiştir. Kaya (2008), Fransa'daki Türkler özelinde yaptığı araştırmada en genel anlamda "Özellikle son yirmi yılda Batı Avrupa'da yaşayan göçmenlerin, sanayisizleşme süreciyle birlikte, işsizlik, yoksulluk, yabancı düşmanlığı ve ırkçılık gibi yapısal birtakım problemlerle karşı karşıya kaldıkları" sonucuna varmıştır (Kaya, 2008, s.36).

Fransa'nın 2000 sonrası göçmen politikası ise iki eksende gelişme göstermiştir. Bunlardan ilki ülkeye "faydalı" olacak göçmenlerin seçimi diğeri de genel göçmenlerin "uyum" sorunlarıdır. Fakat bu durum önceki yılların Fransız göç politikalarından farklı bir durumu temsil etmektedir. Göçmenlerle ilgili önceki konular hak merkezinde; göç etme hakkı, aile hayatının korunması hakkı, sığınmak hakkı ve Birlik içi serbest dolaşım hakkı şeklinde ele alınmışken 2005 yılında Nicolas Sarkozy'nin İçişleri Bakanı, 2017-2012 yılları arasında da Cumhurbaşkanı olduğu dönemlerde yabancı düşmanlığını arttırıcı uygulamalara tanık olunmuştur. Devletçi, ulusalc1, cumhuriyetçi ve etnik ayrıştırmacı ${ }^{9}$ özellikleri olan bu "güvenlik" odaklı uygulamalar toplumsal ve etnik çatışmayı arttırmıştır (Özer, 2015, s.19-30).

Kaya (2008, s.47-49) Fransa'daki bu yapının sosyal yaşantıdaki yansımaları üzerine yapılan bir takım gözlem ve görüşmeler sonucunda oldukça ilginç antropolojik sonuçlara ulaşmıştır. Bu sonuçlardan en belirgini sosyal yaşamda ikircikli yaşamların oluşmaya başlamış olmasıdır. Göçmenler, evde, işte, okulda ve özel yaşamlarında farklı kimliklerle hareket etmeye başlamıştır. İş ve eğitim yaşamında kendilerine yer bulamayan göçmenlerin nefret patlaması yaşadıkları görülmektedir. Bu nefrette, gençlerin tutunamama ve gelecek kaygısına sahip olmaları ile hiç bir yere ait olmayan anarşist tavırlar geliştirmelerinde toplum içindeki somut kazanımlar elde edememelerinin payı oldukça büyük görülmektedir. Nefret

\footnotetext{
9 Sarkozy'in Fransa'daki banliyö olaylarında ayrımcı bir dil politika yürüttüğü haberlere sıkça rastlamıştır: "Gazetecilere 'pedofili' benzetmesi yapması, elini sıkmayı reddeden bir vatandaşa 'kaybol zavallı aptal" demesi ve 2005 yılında Paris banliyölerindeki olayların ardından bölgede yaşayan gençlere 'ayaktakımı' diye hitap etmesi Sarkozy’nin büyük tepki görmesine neden olmuştu (Aljazeera, 2014).
} 
söyleminin hem Fransa'ya hem de Türkiye'ye aynı şekilde yönelmiş olması kimliklerin marjinalleşmesinin göstergesi olarak görülmektedir. Öfke toplumunu oluşturan gençlerin sadece Türklerden değil, Arap, Afrikalı ve hatta Fransızlardan da oluşması öfkenin şiddetini arttırmaktadır. Ebeveynlerin çocukları ile ilgilenemeyecek şekilde yoğun bir çalışma düzeninde olması da sokağın bir çözüm unsuru olarak öne çıkmasında etkili olduğu görülürken gençlerin yalnızlı̆ yoğun şekilde hissettiğinin altı çizilmektedir.

\section{Bulgular ve Yorum}

\section{Entre Les Murs ve İki Dil Bir Bavul Filmlerinin Karşılaştırılması}

Entre Les Murs (2006), Paris'te göçmenlerin yoğun olarak yaşadığ 20. bölgede bulunan Collège François Dolto adlı bir okulda geçmektedir. Fransızca öğretmeni François Marin ve meslektaşları farklı etnik kimliklerden gelen öğrencilerin çoğunlukta olduğu bir okulda görev yapmaktadır. Her bir öğretmenin öğrencilere yaklaşımı farklıdır. Film, François Bégaudeau'nun "Entre les Murs (Duvarların Arasında, 2006)" adlı romanından adapte edilmiştir. Filmin senaryosunu Laurent Cantet, François Bégaudeau, Robin Compillo kaleme almıştır. Film okul yönetimi, öğrenci ve öğretmenler arasındaki çatışmacı ilişkilere odaklanmaktadır. Filmin yapımcılığını çok sayıda Fransız yapım şirketi üstlenmiştir (Mennesson, 2014).

Entres Les Murs filmi hem belgesel hem de kurmaca özelliklere sahip bir film olma özelliği göstermektedir. Filmin belgesel özellikleri arasında François Bégaudeau'nun gerçekte öğretmen oluşu ve gerçek yaşamı ile filmde oynayan yirmi dört öğrencinin neredeyse tamamının adı geçen okulda öğrenci oluşların, velilerin gerçek kişiler olması, eş zamanlı üçlü kamera kullanımı, yakın ve hareketli planların tercih edilmesi, iç ses, doğaçlamalar, ritmik ve hareketli kurgu, müzik yerine daha çok doğal seslerin tercih edilmesi ve yoğun şekilde diyalogların varlığı yer almaktadır.

Filmin yönetmeni Cantet, 2008 Kasımında New York'ta Jeniffer Merin'e verdiği röportajda öğrencilerin ancak belli bir iş akışı içinde kendilerini bulduklarını, normalde insanların kamera önünde role büründüklerini ve kendilerini gizleme riskinin bulunduğuna dikkat çekmiştir. Filmin kurgusal mı belgesel mi olduğu tartışmasına 1şık tutacak bu yaklaşım 
Cantet'nin filminde izlediği yolu da ortaya koymaktadır. Film belgesel olamayacak kadar kurgusal, kurgu sayılamayacak kadar da belgesel özelliklerini barındırmaktadır. Filmi özel kılan taraf da budur. (Merin, 2008) Cantet'e göre belgesel anlatısında gelişigüzel bir anlatım olduğundan "gerçek olan" gerçekliğiyle belirginleşmemektedir. Cantet bu filminde kendi ifadesiyle sadece gerçeği ve gözden kaçanları göstermek istediğini vurgulamıştır. Çevremizde olup bitenleri takip etmekte zorluklar yaşayan insan algısı ve onun sınırlı takip gücü çevresinde olup bitenleri kavrama noktasında yetersizlikler barındırmaktadır. Bu sebeple Cantet, yer yer akışa müdahale ederek filmin kurgusal yanını da ayakta tutmayı tercih etmiştir. Kurgu her ne kadar öznel bir yöntem gibi gözükse de Cantet bu filminin kurgusunda sadece kendi tercihlerini değil diğer oyuncuların da tercihlerini sahneye taşıdı ̆̆ını söylemektedir. Dolayısıyla filmdeki gerçeklik en ileri seviyededir. Filmin gerek Avrupa gerekse de Amerika'da elde ettiği başarılarda bu sentezin başarısı rol oynamıştır.

İki Dil Bir Bavul (2008) ise Denizlili Emre (Aydın) öğretmenin yaşadığ1 şehirden çok uzakta Güneydoğunun bir yerinde; Şanlıurfa'nın Demirci köyünde Türkçe bilmeyen öğrencileriyle geçirdiği bir yılını konu edinmektedir. Dil ve kültürel iletişim (iletişimsizlik) sorunlarına etraflıca bir bakış açısı ile alındı̆̆ı filmde öğretmenin psikolojisi, milli eğitim politikalarının bölgedeki güncelliği sosyolojik bir gözle değerlendirme konusu edilmiştir. Türkiye-Hollanda ortak yapımı olan filmin yapımcılığını Bulut ve Perişan Film üstlenmiştir. Boğaziçi Üniversitesi'nin bünyesinde faaliyet gösteren Mithat Alam Film Merkezi'nden Yamaç Okur ile Nadir Öperli ise ortak yapımcı olarak filmde temel bir rol üstlenmiş görünmektedir. (Sinematürk, 2008; Beyazperde 2008; Aljazeera, 2015)

İki Dil Bir Bavul (2008) filminin kamera arkasında yönetmenlerle yapılan söyleşide filmi özgün kılan hususun Duvarların Arasında filmindeki gibi öğretmenin eğitim sürecinde ne yaşadığı ne düşündüğünün müdahalesiz veya kısmen müdahale edilerek dengeli şekilde öne çıkarılması olmuştur. Klasik televizyon belgesellerinde verildiği gibi Kürt toplumu, anadilde eğitim gibi konu başlıklarında doğrudan bir tartışma başlatılıp öğretmen, öğrenci ve ailelerin düşünce açıklamasını beklemek yerine karakterlerin bu konularla sınırlı kalmayıp farklı konu başlıklarında bir eylem içinde olabileceği ihtimali üzerinden hareket edilmesi film içindeki “duygusal gerçekliği”" ve dolayısıyla “özgünlüğü” arttırmış durumdadır. 
Bu bakımdan filmin, Fransız filmi ile benzer bir yaklaşım içinde olduğu söylenebilir.

Yönetmenlerle yapılan söyleşide ön plana çıan diğer meseleler arasinda ise Türkiye'nin özellikle doğusunun feodal toplumsal düzeninin bir parçası olarak ciddi alt yapı sorunları barındırdığı, küçük yaştaki çocukların kendi ana dillerini öğrenmeden yabancı bir dil öğrenmelerinin onların gelişimini olumsuz etkilediği, okul faaliyetlerinin dışarıdaki dünyanın zorunlu koşullarına bağlı olarak sürekli kesintiye uğramasının eğitimi işlevsizleştirdiği, kültürel kodları çözmeden dil öğrenmenin ve öğretmenin imkânsız olduğu ve milli eğitimin bayrak, poster ve marştan öte gitmeyen sembolik anlamlarla temsil edildiği ve böylelikle "rasyonel" bir değişimin oluşamadığı görüşleri öne çıkmaktadır.

\section{Entres Les Murs'un Senaryosunda Ulus Düşüncesi ile İlişkili Sahneler}

\section{Yeni Ĕ̆itim Öğretime Öğretmenlerin Hazırlık Toplantı Sahnesi}

Bu sahnede öğretmenler yeni eğitim-öğretim döneminin açılışına dair görüşlerini paylaşmaktadır. Bu toplantıda göçmenlerin varlığı potansiyel sorunlu olarak kabul edilmekte ve öğretmenlerde bir tedirginlik uyandırmaktadır.

\section{Fransızca Öğretmeninin Öğrencilerle Kurallara Uygun Dil Kullanı- mını Tartışması}

Bu sahnede ise Fransızca öğretmeninin Fransızcanın kurallara uygun biçimde nasıl kullanılması gerektiğini öğrettiği sahnede öğrencilerin tepkisi ile karşılaşmaktadır. Öğrenciler, Fransızcanın sokakta bu şekilde konuşulmadığını savunmaktadır.

\section{Fransızca Öğretmeninin Öğrencilerle Cinsel Tercihleri Tartışması}

Bu sahnede öğrencilerin Fransızca öğretmeninin cinsel tercihini öğrenmek istemelerine karşın öğretmenin bu soruya cevap vermediği tercihlerin özel kalması gerektiğine yönelik yorumda bulunduğu gözlenir. Buna karşılık öğrenciler öğretmeni homoseksüellikle suçlar. 


\section{Bilgisayar Öğretmeninin Öğrencilerden Dert Yanarak Hışımla Öğretmenler Odasına Girdiği Sahne}

Bu sahne bilgisayar öğretmeninin öğrencilerden umudunun tamamen kesildiği ve onlara hakaretlerde bulunduğu bir sahnedir.

\section{Fransızca Öğretmeninin Öğrencilerden Otoportrelerini İstediği Sahne}

$\mathrm{Bu}$ sahnede ise Fransız öğretmeninin öğrencileri tanımak istemesi konu edilir. Öğrencilerden, biçimde özgür olacakları şekilde bir oto portre çalışmasında bulunulmasını isteyen öğretmen milli kimliklerinden uzak kendi içlerinde dünyaları keşfetmeye çalışırken onların kendilerine özel dünyaları ile karşılaşır.

\section{6. ̈̈̆gretmenler Kurulunda Ceza-Ödül Sisteminin Tartışıldı̆̆ı Sahne}

$\mathrm{Bu}$ sahne öğretmenlerin kendi aralarında öğrenciler arasında uygulanacak ödül-ceza sistemini tartıştıkları sahnedir. Bu sahnede öğretmenler öğrenci davranışlarını puanlamayı önermekte belli bir puanın altında kalan öğrencilerin ceza alması gerektiğini savunmaktadır.

\section{Fransızca Öğretmeninin Öğrencilerle Saygı Üzerinde Tartıştı̆̆ı Sahne}

Bu sahne ise Afrikalı Khoumba adlı öğrencinin kendilerine saygı gösterilmediğini itiraf ettiği sahnedir. Öğrencinin işaret ettiği saygısızlık, kamusal düzeyde değil entelektüel düzeyde fikirlere ve inançlara karşı yapılan saygisızlık durumudur.

\section{8. Öğretmenler Kurulunun Öğrenci Performansların Değerlendirdikleri Sahne}

$\mathrm{Bu}$ sahne ise öğrencilerin performanslarının öğretmenlerce kritik edildiği sahnedir. Bu sahnede iki de öğrenci temsilcisinin bulunduğu gözlenmektedir. Demokratik bir ortam görüntüsü verilen sahnede katılımcılık ve çoğulculuk ilkelerinden hareket edildiği görülmektedir. 


\section{Fransızca Öğretmeninin Öğrencilerden Cezayirli Esmeralda'ya Ha- karet Ettiği Sahne}

Bu sahne ise 8 numaralı sahne ile doğrudan ilişkilidir. Bir önceki sahnede iki öğrenci temsilcisi kurul değerlendirmelerinde gevşek/ilgisiz davranışlarda bulunmuş ve bu da Fransızca öğretmeninin hakareti ile sonuçlanmiştır.

\section{Hakaret Üzerine Şiddete Başvuran Afrikalı Öğrenci Süleyman'ın Savunmasının İstendiği Disiplin Kurulu Sahnesi}

$\mathrm{Bu}$ sahne ise öğretmenin yaptığı hakarete Afrikalı öğrenci Süleyman'ın verdiği ölçüsüz tepkiyi göstermektedir. Bu sahnede Süleyman'ın disiplin kuruluna sevk edildiği görülürken disiplin kurulunda ise kendisine hakarette bulunan Fransızca öğretmeninin yer aldığı çelişkili şekilde görülmektedir.

\section{Entres Les Murs Filminin İçerdiği Söylemlerin Analizi}

2 numaralı sahnede Fransızca öğretmeninin Fransız dilinin kurallara uygun biçimde nasıl kullanılması gerektiğini öğrettiği sahnede öğrenciler öğretmenlerini "burjuvaların konuştuğu Fransızcayı" öğretmekle suçlamaktadır. Öğrencilerin gözünde Fransız halkı ve onların konuştuğu dil sokakta yaşanan dilin (kuralsızlık veya argo) bir temsilcisi olmaktan uzak aristokrat-elit değerlerin bir temsilcisi konumunda görülmüştür.

3 numaralı sahnede öğrencilerin Fransızca öğretmeninin cinsel tercihini öğrenmek istediklerinde öğretmene "homoseksüel" yaftasında bulundukları görülmektedir. Bu durum tek tip eril ya da dişil kimliklerin ötesinde metropol atmosferindeki çoklu kimliklere işaret etmektedir. Zamanımızın tekil ulusal kimlikleri yerini çoklu kimliklere bırakmıştır bu da ulusal eğitim düzeni içinde bir tartışma konusu olarak filmde yer almaktadir.

4 numaralı sahne bilgisayar öğretmeninin öğrencileri birer "hayvan"a benzetmesi Fransız toplumu ile göçmenlerin biyolojik bakımdan türdeşlik içermediklerini düşündüklerini göstermektedir. Böyle bir bakış açısının zamanla kültürel türdeşlik kurabilme ihtimali de ortadan kalkmaktadır. 
5 numaralı sahnede ise Fransızca öğretmeni tarafından öğrencileri tanımak için kendilerinden oto portre çalışması yapması istenir. Kimisinin kendisini kompozisyon şeklinde kimisinin de fotoğraflarla ifade ettiği görülür. Göçmenleri tektipleştirici bir bakış açısını kırmak adına onların her birinin farklı birer öznel dünyası olduğu bilgisi verilir. Nitekim sınıfın en sorunlu öğrencilerinden olan Afrikalı Süleyman'ın kolundaki dövmede yazılı olan "sükûta ve yerinde konuşmanın önemine" dair ifade sistemin hırçınlaştırdığı bir göçmenin de kendine özgü düşünceleri olabildiğini göstermektedir.

Öğretmenlerin kendi aralarında öğrenciler arasında uygulanacak ödül-ceza sistemini tartıştıkları 6 numaraları sahnede ise öğretmenlerin ödülden çok ceza konusunu tartıştıkları görülür. Tartışmalar arasında cezanın "eğitici" tarafına ve insanı olumlu yönde gelişmeye sevk edeceğine duyulan inanca tanık olunur. Öğretmenler arasında bu tavrı destekler nitelikte bir puantaj sistemi önerilir. Bu puantaj sistemi 0-6 rakamları arasındadır ve öğrencinin, hatalı davranış gösterdiğinde puanın azalırken; 0 (sıfır) rakamını bulduğunda da cezalandırılması önerilir. Bu uygulama öğrencilerin tümünün potansiyel hatalı oldukları uyarmasını yapacağından "korku" modeli üzerinden eğitilmeleri ve dolayısıyla "ayrıştırma" yaşamaları ihtimalini gündeme getirmektedir.

7 numaralı sahnede Khoumba'nın günlüğünde kaleme aldığı, "saygı" konusundaki kaygılarını dile getirmesi bir saygı sorununun varlığına işaret etmektedir. François'nın saygı konusunda azami dikkat göstermesine rağmen günlükte kendisinin saygıdan yoksun olarak betimlenmesi biçimsellikten öte samimi bir saygı beklentisinin varlığına delil olarak görülebilir. Diğer öğretmenlerle öğrenciler arasında saygıyı zedeleyecek diyalogların yaşanmış olması François'nın gösterdiği saygıyı da gölgelemektedir. Bütünlükçü anlayışta olması gereken bir eğitim sisteminin anlık tepkilerden beslenmesi eğitimin öğrenciler nezdinde ciddiyetine de gölge düşürmektedir. Bu örnekte fiziksel bakımdan bir arada olan ama duygularda bir ayrıştırma içeren eğitim sisteminden söz etmek mümkün gözükmektedir.

8-9 ve 10. Sahneleri birlikte değerlendirmek gerekmektedir. 8. Sahnede öğrenci temsilcilerinin kuruldaki gayri resmi tavırları Öğretmen François'nın kendilerine "kaldırım yosması" benzetmesi ile bir tartışmaya dönüşmüş sonrasında Afrikalı öğrenci Süleyman'ın ölçüsüz tepkisi ile derste 
konuyla ilgisi olmayan bir öğrencinin yaralandığ 1 görülmüştür. Bu aşamada Süleyman'ın disiplin kurulunda yargılandığ 10.sahnede ise François'nın hâkim, Süleyman'ın ise sanık olarak ifadesine başvurulmuştur. Bu durum bir öğrencinin ne kadar fikirde özgün, evde başarılı ya da duruma özgü haklı olsa da bir göçmen olduğu için yargı sistemi karşısında eşit olmadığını göstermektedir.

\section{İki Dil Bir Bavul'un Senaryosunda Ulus Düşüncesi ile İlişkili Sahneler}

\section{1. Çorak Arazideki Okul Sahnesi}

Eğitimin değerini kavratacak bir emarenin bulunmadığ okul imgesi verilir. Çorak bir arazide okul imgesi eğitimin o araziyi yeşertebileceği anlamı da taşımaktadır.

\section{Atatürk ve Türk Bayraklarn Sahnesi}

Boş sınıfta Atatürk portresi ve Türk bayrakları ile süslü bir sınıf görüntüsü verilir.

\section{Kuyudan Su Çeken Öğretmene Yardım Eden Öğrencilerin Sahnesi}

Kuyudan su çeken öğretmen bidonları evine taşırken öğrencilerin öğretmene yolda yardım ettikleri görülür.

\section{Köylülerle İlk Buluşma Sahnesi}

Bu sahnede öğretmen velilerle buluşur ve kendisinin Batıdaki bir şehirden geldiğini; geldiği yerde yüksek apartmanların olduğunu ifade eder. Doğuya ilk defa geldiğini ve zorlandığını belirtir.

\section{5. $\quad$ Öğretmenin Öğrencileri Aradiğı Sahne}

Okulun ilk gününde öğrencilerin okula gelmediğini fark eden öğretmen onları aramaya koyulur. Çoğu evlerinde yoktur, tarlada, bağda çalışmak- 
tadır. Bir kısmı da sokakta oynamakta okula gitme mecburiyetinden habersizdirler. Bu durum ailelerin okula verdiği önceliğin ve önemin bir göstergesidir.

\section{Ailelerin Çok Fazla Çocuğu Olduğunun Gösterildiği Sahne}

Bu sahnede annenin her bir çocuğu ile yeteri düzeyde ilgilenemediği görülmektedir. Özellikle bir kız çocuğunun saçlarının erkek gibi taranması kadınlığa bakış açısını da göstermektedir.

\section{7. Öğrencilerle İlk Tanışma Sahnesi}

Öğretmen öğrencilerle tanışmaya çalışır. Adlarını ve ebeveynlerinin adlarını sorar. Öğretmenin sevecen ve sempatik tavırları dikkat çeker. Öğretmen ve öğrenciler arasında sevgi bağı kurulduğu gözlenir.

\section{Okulda Hangi Dili Konuşacaklarının Belirtildiği Sahne}

Bu sahnede öğretmen öğrencilerin sınıfta daima Türkçe konuşmalarını ister. Bunun da nedeninin eğitim sistemi içinde 8 yıllık bir dönem içinde Türkçe konuşarak gelişebilecekleri olduğunu açıklar.

\section{9. $\quad$ Öğretmenin Annesi İle Dertleştiği Sahne}

Öğretmen bu sahnede öğrencilerin Türkçeyi hiç bilmemelerinden yakınır. Bu durumda ders anlatmak yerine dil öğretmeye çalıştığından annesine telefonda sürekli şikâyette bulunur. Şikâyet durumu öfkeli değil şaşkınlık belirtir şekilde gerçekleşir.

\section{0. Öğretmenin Resimlerle Doğal Dünyayı Anlattı̆̆ı Sahne}

Öğretmen poster şeklindeki görseller kullanarak öğrencilerin çevrelerindeki dünyayı algılamalarını sağlamaya çalışır. 


\section{1. Öğretmenin Andımızı Tahtaya Yazdı̆̆ı Sahne}

Bu sahnede öğretmen "Andımız" 1 tahtaya yazar ve öğrencilerin ezberlemesini ister. "Ne Mutlu Türküm Diyene" sözü büyük harflerle yazılır.

\section{2. Ö̆̆retmenin Kelimeleri Öğrettiği Sahne}

Öğretmen tahtaya el çizer ve el kelimesinin türevlerini yazar ve "el ele" olma durumunu vurgulayıp öğrencilerin kendi aralarında el ele tutuşmalarını söyler.

\section{Veli Toplantısı Sahnesi}

Öğretmen velilere öğrencilerin durumundan bahseder. Deftersiz kalemsiz gelen öğrenciler ile hiç Türkçe bilmeyen öğrencilerden duyduğu rahatsızlığ 1 dillendirir. $\mathrm{Bu}$ ifadeleri diğer velilere tercüme etmek isteyen bir veli ise öğrencilerin okula temiz bir şekilde (giyisi, önlük ve kalem-defterleri örneğin) ne erken ne geç zamanında gelmeleri ve evde sakin olmaları gerektiğini diğer velilere aktarır.

\section{Emre Hocanın Bir Velinin Evine Misafir Olarak Davet Edildiği Sahne}

Bu sahnede, davet eden velinin 1990'l1 yıllarda Almanya' ya işçi olarak gitmek için başvuru yaptığı esnada karşılaştığı bir durumu anlattı̆̆ görülür. Kendisine bir form verilmiş ve bildiği yabancı dilleri yazması istenmiştir. Kendisi de forma yabancı dilinin Türkçe olduğunuı yazmıştır. Anadilinin ise Kürtçe olduğunu söylemesi üzerine ise yetkili kadının "fahişe gibi" güldüğünü belirten veli kendisinin hor görüldüğ̈̈nnden yakınır. Emre öğretmen bu tavrın yanlışlığını tasdik eder. Bunun üzerine veli o bölgedeki çocukların okula eğitim almaktan çok Türkçe öğrenmek için gittiklerini ve bunun da ortalama 5 yıl sürdüğünü ve ancak Türkçe öğrenebildiklerini itiraf eder. 


\section{Okulun Bahçesine Ağaç Dikilen Sahne}

Öğretmen, öğrencilerle birlikte okulun çorak bahçesine ağaç diker. Filmin başındaki çorak sahneyi yeşillendiren öğretmen ve öğrenciler; yani eğitimdir. Bu sahne filmin başındaki sahnenin içerdiği eğitimsizlik sorununa ilişkin bir cevap niteliğindedir.

\section{Rojda'nın Okula Gelmediği Sahne}

Öğretmen öğrencisinin evine gidip neden okula gelmediğini sorduğunda evde kardeşlerine baktığını öğrenir. Bu durum göstermektedir ki kimi kız öğrenciler tam okula adapte olduklarında evdeki gereksinimlerden ötürü eğitimlerini kesintiye uğratabilmektedir.

\section{23 Nisan Kutlaması Sahnesi}

Öğretmen günün anlam ve önemini öğrencilere sorduğunda öğrencilerin kendisine "padişahlıktan kurtulup meclis yönetimine geçildiği" yönünde cevap verdiği görülür. Öğretmen sonrasında bu bayramı dünyada yalnız Türk milleti ile Türkiye'nin kutladığını vurgulamakta ve öğrencilerin bunun kıymetini bilmelerini istediği görülmektedir.

\section{Karne Dağıtma Sahnesi}

Öğretmen Zülküf'e karnesini verdiğinde elini öpmesini söyler fakat Zülküf bunu tam anlayamaz ve sadece öper. Öğretmen başına da koymasını söyler ve ondan sonra koyar. Öğretmen öğrencisinden kitap okuyup yazı yazmasını ister. Evdeki karne değerlendirme sahnesinde ise velilerin oğullarının başarısını önemsedikleri görülürken kızların başarısızlığını yorumsuz bıraktıkları gözlenir.

\section{9. Öğretmenin Okuldan Ayrıldı̆̆ı Sahne}

$\mathrm{Bu}$ sahnede ise öğretmen okuldan eşyalarını toplayıp arabasına yükleyerek ayrılırken kamera kayalıkların arasında oynayan öğrencileri gösterir. 
Bu sahne öğrencilerin bölgede yaşadığı sosyolojik koşulları vurgular. Öğrenciler yılanlarla oynadıklarını birbirlerine anlatırken sahne daha sonra çıplak şekilde koşarak dereye atlayan çocukların eğlenir halini göstererek devam eder. Çocuklar modern kent sosyolojisinde oldukça uzak bir dünyada yaşarlar. Orada süregiden bir yaşam vardır. Fakat öğretmenler buraya belli bir dönem için gelir; şark hizmet süreleri bitince de geri dönerler. Oradaki yaşamsa devam eder.

\section{İki Dil Bir Bavul Filminin İçerdiği Söylemlerin Analizi}

1 ve 2 numaralı sahneler feodal düzen içinde konumlanan bir eğitim kurumunun yalnızlı̆̆ 1 ve yoksunluğu gösterilmektedir. 2 numaralı sahnede ise Türk milliyetçiliğinin sembolleri olarak Atatürk ile bayrak figürünün gösterildiği görülmektedir. Atatürk'ün eğitimdeki devrimlerinin hedeflediği muasır dünya ötesi Türkiye'nin burada bir çelişki ile karşılaşmış olduğu vurgulanmaktadır.

3 numaralı sahnede ise doğu insanının öğretmene duyduğu saygının göstergesi temel ihtiyaçlar konusunda açığa çıkar. Öğrencilerin yardım etmesinin ardından velilerin de gelip öğretmenin su problemini çözüp çözmediklerini sordukları görülür.

4 numaralı sahnede ise öğretmen velilere özellikle Batıdan gelen bir öğretmen olduğunu ve her iki yaşam biçiminin keskin bir biçimde ayrı olduğunu anlattığı görülür ve Doğu'ya adapte olmanın zorluğunu vurgular.

5 numaralı sahnede ise öğretmenin öğrencileri evlerinin olduğu mahallerde araması gösterilir. Veliler ortada olmadığı gibi çocuklar da yoktur. Hep birlikte tarlalara, işe gitmişlerdir. Bu durum bölgede çocukların da küçük yaşlarda ekonominin bir paçası olarak feodal düzeni inşa eder şekilde varlık gösterdikleri görülür. 2008'in Türkiye' sinde dahi toprak reformunun tam anlamıyla gerçekleştirilemediği vurgulanır.

6 numaralı sahnede ise bir ailede çok fazla çocuğun olduğu ve özellikle kız çocuklarının erkek gibi yetiştirildikleri gözlenir. Erkek egemen feodal düzen içinde çocukların toplumsal cinsiyet rolleri de erkek gibi davranmak şeklinde belirginleşmektedir. Özellikle saç tarama sahnesinde kız öğrenciye yapılan muamele erkek egemen toplumun davranış biçimini gösterir niteliktedir. 
8 ve 9 numaralı sahnelerde Türkçe'nin okul içindeki önemine değinilir. Eğitimin sürekliliği açısından Türkçenin etkin bir şekilde öğrenilmesi gerektiği üzerinde durulur. Fakat buradaki sorunu öğretmen görev yaptığ 1 yerde kimseyle konuşamamakta telefonda annesi ile paylaşmaktadır.

10 numaralı sahne ise öğretmenin, öğrencilerin yaşadığı doğayı Türkçe kelimelerle anlamlandırmalarını istediği sahnedir. Sadece harfleri, sayıları değil doğayı da Türkçe kelimelerle anlayarak dil bilinci bakımından belli bir gelişmenin hedeflendiği gösterilmektedir.

11 numaralı sahnede ise öğretmen öğrencilere andımızı öğretir ve ezberlemelerini ister. Bu sahneden sonraki diğer sahnelerde öğrenciler andımızı ezberlemiş şekilde okula gelir.

12 numaralı sahnede ise el ele tutuşmak kavramı üzerinde durulur. $\mathrm{Bu}$ sahne ile 7 ve 15 numaralı sahne ortak bir mesaj içerir: Kürtlerle Türkler sevgi üzerine birbirine yaklaşmalı el ele vererek feodal düzeni ortadan kaldırabilmelidir. Öğretmen ve öğrencilerin ortak şekilde ağaç dikme faaliyetleri yaşadıkları ülkeyi feodal çoraklıktan kurtarıp yeşerterek verimli bir ülke haline getirme metaforunu içermektedir.

13 numaralı sahne eğitimin öneminden ziyade modern düzenin kurallarının velilere anlatıldığı bilgileri içermektedir. Özellikle temizlik, zamanında gelme ve evde bir düzen tutturmaları gerektiği üzerinde durulur. Okuldaki sistemin düzgün işleyebilmesi için temizlik, zaman yönetimi ve ev düzeninin (ailelerin öğrencilere eğitim için destek çıkması) önemi üzerinde durulur.

14 numaralı sahne dili ve milleti ile insanların alay edilmemeleri gerektiği yönünde anti-faşizan bir söylemi içermektedir. Hal ve davranışları, doğdukları ve yetiştikleri bölge, konuşma biçimleri ve kıyafetleri nasıl olursa olsun bir toplumun fertleri alay konusu yapılmamalıdır düşüncesinin bu sahnede öne çıktı̆̆ 1 görülmektedir.

16 ile 18 numaralı sahnelerde eğitimin sürekliliğine vurgu vardır. İlkinde Rojda'nın ikincisinde de Zülküf'ün okula, okumaya ve yazmaya devam etmeleri öğretmenleri tarafından özellikle istenir. Öğretmen okula gelmeyen öğrencilerin evlerine kadar bu sebeple gider. Burada vurgu eğitimin öneminden çok onun sürekliliğinedir.

17 numaralı sahnede ise 23 Nisan kutlamaları ile yönetim sisteminin eleştirisi yinelenmektedir. Feodal düzen yerine modern düzenin toplumda hâkim kılınması gerektiğinin altı çizilir. Tek millet, tek dil vurgusu 
yinelenirken aynı zamanda meclise (parlamenter) demokrasiye ve dolayısiyla toplumsal kesimlerin temsiline de atıfta bulunulur.

18 numaralı son sahnede ise eğitimin geliştirdiği söylem ile çocukların var olduğu doğal koşulların ürettiği söylemin ortaya koyduğu çelişki görünür kılınmaya çalışılır. Çocuklar zorlu doğa koşullarında yaşamaktadır ve içinde bulundukları feodal düzen modern dünyanın ulus ve dil bilincini fark etmekten uzaktır. Onların içinde bulundukları doğal koşulları değiştirmeden okulun ürettiği söylemin bir parçası olabilmek çok kolay gözükmemektedir.

\section{Sonuç, Tartışma ve Öneriler}

Tarihsel doğuşu dikkate alındığında belli bir vatan üzerinde birlikte yaşama ve ortak bir gelecek inşa etme isteğinin ulus kavramının tanımı içinde yer aldığı ifade edilirken günümüzde küreselleşme ile birlikte bu tanımın uygulamada farklılaştığı görülmektedir. Endüstri devrimleriyle başlayan ve modern (endüstri) sonrası dönemde de devam ettirilen süreçte ulus kavramının ekonominin bir parçası olarak değerlendirildiği ve faydacı bir yaklaşımla ele alındığı görülmektedir. Modern anlamda eğitimli, modern anlamda kültürlü ve modern hayatın hukuksal düzeninde anlam bulan bir milli kimlik kabulünün geliştiği görülmektedir. Bu bakımdan her iki filmde de ulus kavramının yorumundaki bu kabul açık biçimde görülmektedir. Her iki filmde burjuvazi toplumunun değerleri olarak matematiksel düşünce, zaman yönetimi, sembolik sayg1, faydacılık, bireycilik, belleksizlik, girişimcilik ve temizlik gibi kavramlar "modern ulusal" değerler olarak ön plana çıkmaktadır. Filmlerin görünür kılmaya çalıştığı nokta ise toplumun modernleştirilme çabasını sahiplenen devletin politikaları yerine kişilerin (öğretmenlerin) bireysel çabalarının varlığidır.

Her iki filmde François ve Emre öğretmen öğrencileri anlamaya onlarla gerçekten diyalog kurmaya çalışan idealize karakterler olarak karşımıza çıkmaktadır. Konuşmak yerine yazmak, düşünmek yerine okumak öğrencilerin kendilerini daha iyi ifade etmeleri açısından faydalar (pragmatizm) barındırmaktadır. Fakat her iki filmin son sahnesinde Esmeralda'nın François'ya yaklaşıp bir şey öğrenmediklerini dile getirmesi ile Zülkif'in 
"yazın kitap okumayacağım" şeklindeki çıkışı okuldaki bu idealist çabanın gölgede kaldığını göstermektedir. Gerek Fransa'daki gerek Türkiye'deki egemen-öteki çatışmasının temelinde öğrencilerin feodal düzenden modern toplum düzenine geçememiş olmaları yer almakatdır. Ortada sistemsel bir çabasızlık varken François ve Emre öğretmenin kişisel çabaları yetersiz kalmaktadır. Bu kişisel çaba öğrencileri kısmen dönüştürürken sistemsel çabasızlık öğrencilerin ebeveynlerini, okul dışı yaşamlarını ve kişisel yeteneklerini modernleşme sürecinin dışında tutmaktadır.

Makalenin ilgili kısımlarında belirtilen tarihsel gelişmeler bağlamında; gerek Türk gerekse Fransız siyasal tarihinin uluslaşma eksenli gelişimi dikkate alındığında, modern anlamdaki uluslaşmanın kültürel zemininin her iki ülkede toplumun bütününe doğru yeterince yaygınlaştırılamadığ 1 ve daha çok güvenlik odaklı olarak askeri ve bürokratik çözüm önerilerine öncelik verildiği görülmektedir. Her iki toplumun uluslaşmadaki yetersizlikliklerinin nedenleri arasında kültürel türdeşliğin oluşamadığı bir mondernizasyon süreci yer almaktadır. Nitekim filmlerde de işlenen ulusal kurumların disiplin, güvenlik ve yasalar çerçevesinde hareket ettiği ve ötekinin gelişimi ile yakından ilgilenmediği görülmektedir.

Her iki filmde de ötekilerin kültürel anlamda içinde bulundukları toplumla ortak bir dil kuramadığı görülmektedir. Fransız ve Türk medeniyetini oluşturan zengin edebi, sanatsal, kültürel ve bilimsel birikimin hoşgörü, anlayış, empati, diyalog ve etkileşim biçiminde yer alarak eğitim müfredatında değerlendirme konusu yapılmadığ1 gözlenmektedir. Bu durumda dil öğrenmek o kültürü ve medeniyeti öne çıkaran kavramlarla iletişim kurmayı, konuşmayı düşünmeyi ve yaşamayı ifade etmek olarak ötekilerce algılanamamaktadır. Fransız yapımı filmde ırkçı tutum sergileyen yönetim sistemi François'in medeni etkisini gölgede bırakmışken Türk filminde gerçekleşmeyen toprak reformunun uzantısı olan feodal düzen Emre öğretmenin medeni anlamdaki hoşgörülü çabasını etkisiz bırakmıştır.

Her iki filmde "fahişe" (İki Dil Bir Bavul'da) ve "yosma" (Duvarların Arasında' da) gibi kavramların ötekini tanımlamak için kullanıldığı görülmektedir. Bu kavramların hakaret olarak sarf edilmesi iletişimi, diyaloğu ve etkileşimi daha baştan ırksal veya cinsiyetçi öfke zeminine çekmektedir. Her iki film özelinde bakıldığında bu sözleri sarf edenlerin popülist 
politikalardan etkilenerek kendi iradeleri dışında hareket ettikleri görülmektedir.

Ulusalcı yaklaşım içinde olan Fransız toplumu ve onun eğitim sistemi kendinden olmayanlara yaklaşımı sürecinde çatışmacı bir görünüm sergilemektedir. Buna neden olan durum, kendilerinin göçmen gruplardan daha ileri bir düzeyde gelişmişlik yaşıyor olduklarını düşünmeleridir. İnsan hakları, fırsat eşitliği, kişi başına düşen ulusal gelir, teknoloji, ulaşım, demokratik değerler, ifade özgürlüğü gibi kıstaslara göre diğer toplumların kendi gelişmişliklerini yakalayamamış olduklarını düşünmeleri çatışmacı bir tutum sergilemelerine neden olmaktadır. Böylelikle kültürel türdeş olmadıklarını varsayan egemenler öteki ile iletişim kurmakta ve paydaş olmakta zihinsel güçlükler yaşamaktadır. Fakat diğer yandan az gelişmişliğin temel nedeni olarak endüstrileşme ile başlayan kolonileştirme reflekslerini eleştirmedikleri de görülmektedir.

Fransa'da göçmenlerin Türkiye'de ise Kürtlerin ebeveyn ve çocuklar olarak bütünlükçü şekilde bir kaç nesil sürecek şekilde modernize edilememiş (modern yaşamın değerlerini içselleştirememiş olmaları, modern ekonominin bir parçası yapılamamış) olmalarının bedelini hem öğretmenler hem de öğrenciler çekmektedir. Çağın gerektirdiği düşünsel, bilişsel ve psikomotor gelişim parametrelerinin ortak ulus ve medeniyet düşüncesi olarak toplumun tüm kesimlerine eğitim yoluyla aktarılamadığı görülmektedir.

Sinema, kültürler arası diyalog sürecinde fiziksek olarak gözden kaçanları kamera aracılığıyla yakalamakta, algısal düzeyde fark edilemeyen noktaların fark edilmesini sağlamakta resmin bütününü görmek noktasında bir avantaj sunmaktadır. Kurgu ile gerçekliğin harmanlandığı, senaryonun hem yönetmen ve teknik ekip hem de oyuncuların ortak katıl1miyla birlikte oluşturulduğu, mikrofonun öğretmen ve öğrenciye olduğu kadar okulun içinde bulunduğu ekosistemin parçası olarak yönetime, velilere, evdeki yaşantıya ve dahası sokağa uzatılması kurgusal gerçekliğin oturduğu rasyonel zemini daha sağlam kılmaktadır. Her iki filmin izlenildiğinde izleyicilerin kendinden bir parça bulması çok sesli düşünmenin bir göstergesi olarak kabul edilebilir. Öğretmenin eleştirildiği gibi öğrencinin de eleştirilmesi, devletin eleştirildiği gibi toplumun; ilgisizliğin, cehalet ve tutarsızlıkların da eleştirilmesi filmlerdeki gerçekliğin ileri seviyede hissedilmesini mümkün hale getirmektedir. 
Her iki film de göçmen, çok kimlik ve kültürlülük ile milliyetçilik olgularına kültürel süreç ekseninde bakmakta süreci her hangi bir ideolojik söyleme başvurmadan beyazperdeye aktarmaktadır. Milli fertlerden önce insan olma sürecinin koşullarının öne çıkarıldığı her iki yaklaşımda sosyoekonomik ve kültürel bakımdan aynı koşulların yaşanmadığı bir zeminde üretilen her politikanın egemen ile öteki arasında çatışmadan başka bir şey getirmediği değerlendirmesinde bulunulmaktadır. O sebeple milli eğitimden önce eğitim alt yapısının (teknoloji ve insan kaynağı) güçlendirilmesi ve ülkenin bütün kesimlerinde modern toplumsal ekosistemin oluşturulması her iki ülkenin toplumlarının sağlıklı iletişimi için temel düzeyde bir gereklilik durumundadır. 


\title{
EXTENDED ABSTRACT
}

\section{Looking at National Education from the Viewpoint of Cinema: A Comparison of Entre Les Murs (France) and On The Way To School (Turkey) \\ *}

\author{
Serhat Yetimova \\ Aydın Adnan Menderes Üniversitesi
}

Referring to the long historical concept of nation in France and Turkey have different meanings periodically loaded. Considering the current situation and behind these periodic interpretations, there is a fundamental structural effect of the Western-centered political (modern) and economic (capitalist) worldview. Today, depending on the process of globalization, it is witnessed that the idea of nation is interpreted as a concept of migration, terror, asylum, pragmatism and security as a concept kit of neo-liberal economic order.

This article attempts to analyze the approach of Entre Les Murs (2008) and On the Way to School (2008) to the nation and the national education issue by using comparative discourse analysis method as they focus on the national education phenomenon. Another common feature of both films is that their directors have a French and Turkish view of the others. Scenario contents of these films examined in the context of discourse analysis are examined comparatively and "nation" and "others" discourses, which are featured in the dialogues of thoughts, subjects, people, works and symbols, are tried to be understood. The meaning of the concept of nation is evaluated in the light of historical data. As a result of this evaluation, after determining the meaning of the concept of nation in the literature for today, it is examined the harmony of the nation with the debate in the selected films and the relationship it has established with the "others". 
In both films, the teachers who are François and Emre emerge as idealized characters who try to understand students and really engage in dialogue with them. Writing instead of speaking, reading instead of thinking has pragmatism in terms of students' expressing themselves better. However, in the last scene of both films, Esmeralda's approach to François and saying that they didn't learn anything, and Zulkif's response to he will not read books in summer shows that this idealistic effort in the school was overshadowed.

France and Turkey on the basis of social conflict in the society lies in the feudal order that did not pass modern society. While there is a systemic problem, François and Emre's personal efforts are insufficient. While this personal effort partially transforms students, systemic deficiencies push students and their families out of the modernization process.

In the context of the historical developments mentioned in the relevant parts of the article; When the nationalization-oriented development of both Turkish and French political history is taken into consideration, it is seen that the cultural basis of modernization is not sufficiently extended to the whole of the society in both countries and that military and bureaucratic solution proposals are given priority with a focus on security.

One of the reasons for the inadequacies of both communities in nationalization is a process of mondernation where cultural homogeneity cannot occur. As a matter of fact, it is seen that the national institutions, which are also covered in the films, act within the framework of discipline, security and laws and do not pay close attention to the development of the other. In both films, it is seen that the others cannot establish a common language with the society in which they live. It is observed that the rich literary, artistic, cultural and scientific accumulation constituting the French and Turkish civilization is not subject to evaluation in the education curriculum by taking the form of tolerance, understanding, empathy, dialogue and interaction.

In this case, learning languages does not imply communicating with concepts that emphasize the culture and civilization of a nation. While the system of racism in the French-made film overshadowed the marital influence of François, the feudal order in the Turkish film rendered Emre teacher's tolerant effort ineffective. 
Both films look at the phenomena of immigrant, multi-identity and culturalism and nationalism on the axis of cultural process and transfer the process to the screen without resorting to any ideological discourse.

In both approaches where the conditions of being a human is emphasized more than being before national individuals. It is evaluated that every policy produced on a ground where socioeconomic and cultural conditions do not have the same conditions brings nothing but conflict between sovereign and other. For this reason, strengthening the educational infrastructure (technology and human resources) before the national education and establishing a modern social ecosystem in all parts of the country are essential for the healthy communication of the societies of both

\section{Kaynakça / References}

Akkaya, Ru. (2004). Küreselleşme olgusu karşısında ulus sorunu. İstanbul: Legal Yayıncilik

Aktar, C. (2003). Osmanlı Kozmopolitizminden Avrupa Kozmopolitizmine Giden Yolda Ulus Parantezi. (T. Bora ve M. Gültekin ed.), Modern Türkiye'de Siyasi Düşünce içinde (s.77-80.) Milliyetçilik. İstanbul: İletişim Yayınları.

1990'larda Kürt Siyasi Hareketi. (2013). Aljazeera. 26.06.2018 tarihinde http://www.aljazeera.com.tr/dosya/1990larda-kurt-siyasi-hareketi adresinden erişilmiştir.

Cumhuriyet Tarihi Kürt Raporları (2013). Aljazeera. 26.06.2018 tarihinde http://www.aljazeera.com.tr/dosya/cumhuriyet-tarihi-kurt- raporlari adresinden erişilmiş̧ir.

Portre: Nicolas Sarkozy (2014). Aljazeera. 26.06.2018 http://www.aljazeera.com.tr/portre/portre-nicolas-sarkozy adresinden erişilmiştir

İki Dil Bir Bavul'da İkinci Perde (2015). Aljazeera. 26.06 .2018 tarihinde http://www.aljazeera.com.tr/al-jazeera-ozel/iki-dil-bir-bavuldaikinci-perde adresinden erişilmiştir

Kürt Sorununda 12 Yılın Karnesi. (2015). Aljazeera. 26.06.2018 tarihinde http://www.aljazeera.com.tr/al-jazeera-ozel/kurt-sorununda-12-yilin-karnesi adresinden erişilmiştir 
90'larda Ne Olmuştu: Güneydoğu'da Polis ve Asker (2015). BBC.

26.06.2018 tarihinde $\quad$ https://www.bbc.com/turkce/haberler/2015/09/150902 90lar 1 asker polis adresinden erişilmiştir

Filmler (2018). Beyazperde. 26.06.2018 tarihinde http://www.beyazperde.com/filmler/film-186702/ adresinden erişilmiştir

Paris'in Varoşları Yanıyor (2005). CNN Türk. 26.06.2018 tarihinde https://www.cnnturk.com/2005/dunya/11/05/parisin.varoslari.yaniyor/137321.0/index.html adresinden erişilmiştir.

Başlangıçtan Bugüne Gün Gün Çözüm Süreci (2014). CNNTürk. 26.06.2018 tarihinde https://www.cnnturk.com/fotogaleri/turkiye/baslangictanbugune-gun-gun-cozum-sureci?page=113 adresinden erişilmiştir.

Çiftçi, A. (2012). Kürt meselesini filmlerle konuşmak. Bianet. 26.06.2018 tarihinde https://bianet.org/biamag/sanat/142161-kurt-meselesini-filmlerle- konusmak adresinden erişilmiştir.

Delannoi, Gil (1998). Milliyetçilik ve ideolojik kataliz. (Çev. S. İdemen) (J. Leca ed.) Uluslar ve Milliyetçilikler, İstanbul: Metis Yayınları.

Paris'teki Banliyö Ayaklanmalarından 10 Yıl Sonra Sosyal Ayrımcılık Sürüyor (2015).Euronews. 26.06.2018 tarihinde news.com/2015/05/18/paris-teki-banliyo- ayaklanmalarindan10-yil-sonra-sosyal-ayrimcilik-suruyor adresinden erişilmiştir.

Kastoryano, R. (2000). Kimlik pazarlığı: Fransa ve Almanya'da Devlet ve göçmen ilişkileri. İstanbul: İletişim Yayınları

Kaya, A. (2006). Avrupa Birliği bütünleşme sürecinde yurttaşlık, çok kültürcülük ve azınlık tartışmaları: Bir arada yaşamanın siyaseti. (A. Kaya ve T. Tarhanlı ed.) Türkiye'de Çoğunluk ve Azınlık Politikaları: AB Sürecinde Yurttaşlık Tartışmaları. İstanbul: Tesev Yayınları

Kaya, A. (2008). Fransa-Türkleri: Cumhuriyetçi entegrasyon modelinin eleştirisi, (D. Danış ve V. İrtiş (ed.), Entegrasyonun Ötesinde: Türkiye'den Fransa'ya Göç ve Göçmenlik Halleri, İstanbul: İstanbul Bilgi Üniversitesi Yayınları

Larousse, D. (2016). Nationalisme. Larousse. 26.06.2018 tarihinde http://larousse.fr/encyclopedie/divers/nationalisme/72720 adresinden

Mennesson, A. (2014). Entre Les murs the class study guide. Ebookbrowsee. 22.01.2014 tarihinde http://ebookbrowsee.net/entre-lesmurs-the-class- study-guide-pdf-d454680638 adresinden erişilmiştir. 
Merin, J. (2008). Filmmaker Laurent cantet discusess "The Class". Documentaries.about. 20.10.2008 tarihinde http://documentaries.about.com/od/filmmakersatoz/a/laurentcantet.htm adresinden erişilmiştir.

Özer, Y. (2015). Türkiye ve Fransa örnekleriyle uluslararası göç ve yabancı düşmanliğı. İstanbul: Derin Yayınları

Muslims Facing Discrimination In Europe (2013). Press TV. 02.01.2014 ve 26.10.2013 tarihlerinde $\quad$ http://www.presstv.ir/detail/2013/10/26/331408/muslims-facing- discrimination-in-europe/ adresinden erişilmiştir.

Selahattin Demirtaş ve Figen Yüksekdağ tutuklandı (2016). Sabah. 26.06.2018 tarihinde https://www.sabah.com.tr/gundem/2016/11/04/selahattin- demirtas-ve-figen-yuksekdag-tutuklandi adresinden erişilmiştir.

Setav (2011). Şark meselesinden demokratik açılıma Türkiye'nin Kürt sorunu hafizası. Sertav. 26.06.2018 tarihinde http://file.setav.org/Files/Pdf/20130130121531 seta- turkiyenin kurt sorunu hafizasi.pdf adresinden erişilmiştir.

İki Dil Bir Bavul (2008). Sinematürk. 26.06.2018 tarihinde http://www.sinematurk.com/film/25044-iki-dil-bir-bavul/ adresinden

Wenden, C. W. D. (1998). Ulus ve yurttaşlık: Hem rakip hem ortak" (Çev. S. İdemen) ( J. Leca ed.) Uluslar ve Milliyetçilikler.İstanbul: Metis Yayınları.

\section{Kaynakça Bilgisi / Citation Information}

Yetimova, S. (2019). Ulusal eğitim meselesine sinemanın gözünden bakmak: Entre Les Murs (Fransa) ve İki Dil Bir Bavul (Türkiye) Filmleri Üzerine Bir Karşılaştırma. OPUS-Uluslararası Toplum Araştırmaları Dergisi, 14(20), 847-877. DOI: 10.26466/opus.591147 